\title{
Traditional uses of ethnobotanical plants for construction of the Hut and hamlets in the Sitamata Wildlife Sanctuary of Rajasthan, India
}

\author{
Kanhaiya Lal Meena,Vimala Dhaka, Prakash Chandra Ahir \\ Department of Botany, M.L.V. Government College, Bhilwara - 311001, Rajasthan, India
}

Email address:

kanhaiyameena211@yahoo.com (K. Lal Meena)

\section{To cite this article:}

Kanhaiya Lal Meena,Vimala Dhaka, Prakash Chandra Ahir. Traditional Uses of Ethnobotanical Plants for Construction of the Hut and Hamlets in the Sitamata Wildlife Sanctuary of Rajasthan, India. Journal of Energy and Natural Resources. Vol. 2, No. 5, 2013 , pp. 33-40. doi: 10.11648/j.jenr.20130205.11

\begin{abstract}
An extensive survey of the Sitamata Wildlife Sanctuaryof Rajasthan has been made to document the information about ethnobotanical plants being used by them to construct Hut and hamlets. 31 plant species of angiosperms have been recorded along withtheirplant parts used toconstruct of various types of Hut and hamlets in the sanctuary.
\end{abstract}

Keywords: Ethnobotanical Plants, Huts And Hamlets, Sitamata Wildlife Sanctuary, Rajasthan, India

\section{Introduction and Review}

The Sitamata wildlife sanctuary, is one of the pride owner of most unique ecosystem with first richest biodiversity in Flora \& fauna in Southern Rajasthan. It is one and only of the important natural habitats for flying squirrel in India. As the name itself explains the sanctuary is also associated with mythological events, it is believed that Devi Sita (wife of Lord Ram) stayed here during the period of her exile in the ashram of Rishi Valmiki. The Valmiki ashram was situated in the sanctuary, thus sanctuary bears the name of Davy Sitamata and her famous temple is situated in the heart in the forest area. It is spread over the Aravalli and Vindhyanchal mountain ranges and in this forest teak trees of timber value are abundantly present.

The Sitamata wildlife sanctuary is situated in between $74^{\circ} 25^{\prime}-74^{\circ} 40^{\prime} \mathrm{E}$ longitudes and $24^{0} 04^{\prime}-24^{0} 23^{\prime} \mathrm{N}$ latitude. It is situated in the south region of the Rajasthan in ChittorGarh, PratapGarh and Udaipur districts and is extended in tehsils Barisadari, Chhoti sadari, Dhariya wad and PratapGarh. The sanctuary covers an area about 422.95 Sq. $\mathrm{Km}$ in which the total reserved forest area is $345.37 \mathrm{sq}$. The $\mathrm{km}$ and the protected forest area are $77.57 \mathrm{sq}$. Km (Fig. 1).

The Sitamata wildlife sanctuary of Rajasthan, located at the trijunction of Aravalli \& Vindhyan Hill Ranges as well as Malwa Plateau, which harbors its unique and diverse biodiversity. It is important mainly because it forms the northwestern limit of Teak-bamboo forests and the fauna occurring therein. It is exceptional for diversity and the interspersion of habitats, which includes an area of teak stands, wetlands, perennial streams, gentle undulating mountains, natural deep gorges and fine grooves of mixed woodlands.

The network of rivers (Jakham, the Karmoi and the Sitamata) and accompanied riparian vegetation is main characteristic of this sanctuary. All this has resulted in diverse micro and macro habitats that are home to quite a few conservation significant floral species like Acacia catechu (L. f.) Willd., Anogeissus latifolia (Roxb. ex DC.) Wall. ex Guill. \& Perr., Boswellia serrata Roxb. ex Cocls., Buchanania lanzan Spreng., Celastrus paniculata Willd., Chlorophytum tuberosum (Roxb.) Baker, Dendrocalamus strictus (Roxb.) Nees, Ficus benghalensis L., Lagascea mollis Cav., Lannea coromandelica (Houtt.) Merrill., Madhuca indica J. F. Gmelin, Sterculia urnes Roxb. and Tectonia grandis L. f. are major tree species viz. Starred Tortoise, Marsh crocodile or Mugger, Long-bill Vulture, White-rump Vulture, Scavenger Vulture, Pangolin, Ratel, Four horned antelope and Leopard. The forest is interspersed with about 30 villages and their agriculture field that creates a typical mosaic. The agricultural activities coupled with the heavy biotic pressure on domestic livestock, illicit cutting of wood, timber and bamboo and other Minor Forest Produces collection including encroachments, both inside and the periphery exerts enormous pressure on the vegetation are reported. 
Further, though it is endowed with rich natural resources, it is affected by natural calamities and hazards like drought, fire, flood and storm, with drought being a common phenomenon. Various aspects of the study area were mostly extracted from the management plan.

Prior to the publication of Hooker's flora (1872-97), local flora and lists were available for several regions of India but nothing was known in Rajasthan. The lacuna was, however, very amply filled during the middle part of the century and large number of technical and semi technical papers were published.

The work on the flora and present day Botany has been pioneered by Linnaeus with his classic publication Genera plantarum (1737). In India the work on floral exploration had been initiated by Roxburgh (1820-1824) who published "Flora Indica". Later eminent botanists like Hooker and Thompson (1855) published an introductory essay to the flora India and the publication of "Flora of British India" (1872-1897).

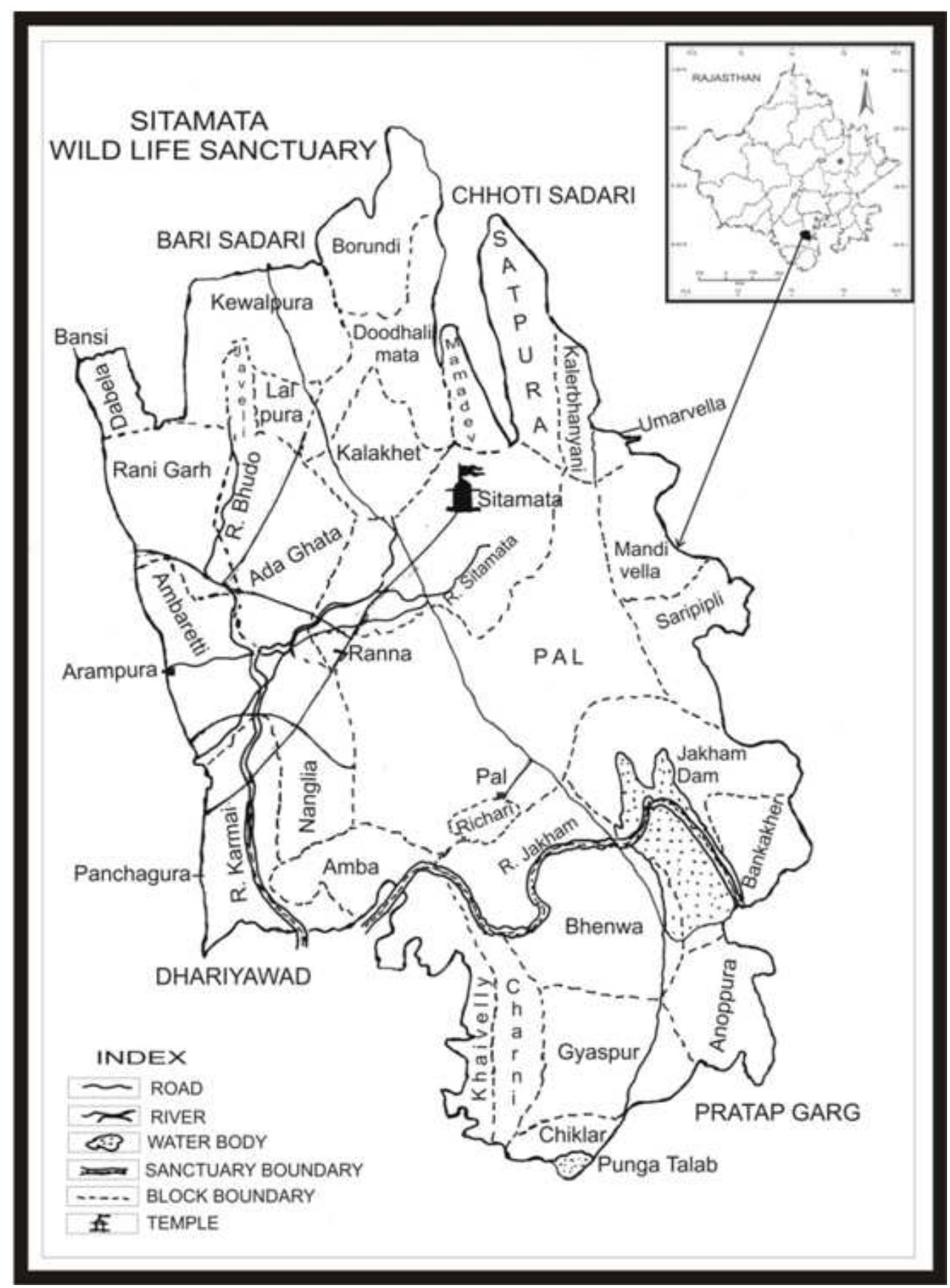

Fig. 1. The Sitamata Wildlife Sanctuary.

In as many as 60 papers, the nomenclature, notes on additions to the flora of Rajasthan or new records for India from this State and notes on extended distribution of various taxa have been reported. Out of 42 publications on floristics, the grasses were dealt in 7 , sedges in 3 and both the grasses and sedges in 2 papers, contribution on 
halophytes in one, while the hydrophytes or marshland plants in 5 and weed flora of various places have been reported in 2 papers. The aspects of economic and harmful plants and the plant introduction, afforestation etc. have been covered in more than 50 papers (Jain, 1970). Shringi (1981) has enumerated the grasses of Jhalawar district. Account of medicinal plants from tribal area of Rajasthan has been provided by Sebastian \& Bhandari (1984a, 84b, 1988), Vyas (1987), Rajawat (1990), Sharma (1991), Singh \& Pandey (1998), Gupta \& Jiyalal (1997), Katewa \& Arora (1997), Katewa \& Guria (1997), Katewa \& Sharma (1998), Sharma \& Asawa (1999), Sharma (2002), Deora et al. (2002), Rathore (2002), Trivedi (2002), Jain et al. (2004, 2005b), Joshi, 1995, Katewa et al. (2003), Katewa \& Galav (2005), Katewa \& Jain (2006), Meena \& Yadav (2006, 2007, 2008, 2009, 2010a, 2010b, 2010c, 2010d), Meena(2011, 2012), Meena et al. (2013), Ahir et al. (2012), Meena 2013 added further the ethnobotanical work from Rajasthan.

\section{Material and Methods}

Ethnobotanical survey was conducted in the Sitamata Wildlife Sanctuary, Rajasthan, India. Field trips conducted with by local people. Generally tribals, who know about the Sanctuary villages, tribes generally do not want to give all the information about plants because they believe that when the plant is disclosed its properties will be lost. For this reason the information collected from the tribes is an important aspect of ethnobotanical study. The peoples who can provide information about plants were consulted and includes experience men and women, elders, birth attendants, bhopa, woodcutters, shepherds and headmen of the community. For authenticity about medicinal properties of plants the information collected during fieldwork were verified at different places through different informants and in different seasons.

Each of the plant species recorded have been collected with the help of the informants and photographs were also taken. The species were identified with the help of reputed flora of India Series- 2 ( Flora of Rajasthan volume 13,Shettey \& Singh (1987-1993) Botanical Survey of India) and recently published Flora of South Central Rajasthan by Yadav \& Meena (2011). The voucher specimen was deposited in the Herbarium of Department of Botany, MLV Government College, Bhilwara.

\section{Observations}

Cultural exuberance of the tribes of the Sitamata wildlife sanctuary is rightly being depicted in several of its elements. The tribes believe in their own god "Bheru bawji" as well as "Mataji" and they prey with them for all purposes. They construct small houses or huts, with one room and veranda made of mud and wood like Anogeissus latifolia (Roxb. ex DC.) Wall. ex Guill. Perr., Terminalia catappa L., Nyctanthes arbor-tristis,Bambusa sp. etc. and are built on the slopes of the hills with their agriculture fields. Maize is the staple food grown by all tribalfamilies. The tribal family honors their guest by a dish prepared from goat or hen. Different duties are allotted for both male and female. The men do the physical labor such as ploughing, harvesting, building the houses as well as hunting. The female carries domestic duties including cooking, nursing and milking the animals and also taking care of the children.

Marriage too like any other tribal communities is held in high position. The tribal communities have permitted freedom in selecting their partners. Young males between the ages of $10-24$ generally marry females who are between $14-18$ years.

Dresses of tribes are quite exquisite. Both the male and females of tribal communities developed an individual style of dressing. Several silver ornaments are in fashion. The woman usually wears black, blue or red blouses with huge petticoats. Men are noted for their white or red turbans.

\section{Huts and Hamlets}

Livings in hamlets that comprise huts scattered sparsely constitute a village. The number of huts in a village may range from a small one like ten-twelve spread over two or more square kilometers. When large the village is called a "Kheri", Dhani is usually made of several huts and tribals of different casts inhabit in different streets. In same localities, however, the tribes live in clusters of several shelters, on plain ground at the foot of the hills. Such shelters denote the accepted authority of one i.e. the father over the sons or the eldest brother over the younger.

Rare still are clustered double storage hutments called "medi". Compact shelter-partners are also seen in villages with a mixed population of tribal and non tribal or in the outskirts of small towns. The typical tribal village is situated between the forest or adjacent to it, near source of natural water supply, whether a river or where water can be obtained through wells or baoris (Step wells)

A tribal generally constructs his hut, close to his agricultural field and often in the field (Plate $1 \mathrm{~A})$. Usually, a tribal's field lies on the slopes below his hut on a hillock. Rarely, affluent tribes, may own two huts, one in the field if it is far away. Besides the huts and fields each village has sacred spots with deities houses in constructingdevras or in constructing sites sheltered by trees like Acacia leucophloea, Ficus religiosa or Ficus benghalensis. The devras are also called as "thanak" Sacred spots may be in the center of the village or on the outskirts (Plate $1 \mathrm{~B}$ ).

A large Azadirachta indica or $F$. Religious or $F$. benghalensis tree or a grove forms the community gathering place. Meetings are also held at the Devras or in the headman's hut. In front of the headman's hut there is an another open house which serves the purpose of entertaining and lodging guests of the village. Such place is called as "Pol". The pol is an open structure with a rectangular roof of timber supported by 3-5 long pillars lenters and covered with a thick mat of Butea monosperma 
leaves \& straw of Triticum aestivum or with sticks of Acacia nilotica and strips of Bambusa, sometimes it is covered with Kelu (kelu is made by soils). It is at the pol that a guest is lodged or the folks assemble for their night palaver or discussion.

The tribal houses are essentially rectangular in construction with the roof sloping down from a common point beyond the upper ends of the two long walls of the huts. These two longer walls are called "Chanda". The roof style prevents overheating by direct scorching sunrays in summers and facilitates the torrential water drops to speedily flow down in rains. A house usually has only one room (sometimes more) separated in 3-4 portions, a corner forms the kitchen, an adjacent one the "Dormitory". While the cattle $\&$ the pet animals are kept on the outer side of the hut (Plate $1 \mathrm{C}$ ). The single entrance is usually on one side of a long wall, though an entrance through the smaller wall is also not uncommon. The house almost never has windows. The walls and the ground are plastered with clay mixed with cow dung or straw of Triticum or Hordium spp.

The cattle may also be tied at the side of the hut inside a fenced enclosure or a semi open construction. Within the hut compound there may also be a raised platform called Dhariya or some times dagla.

A typical tribal house consists of :

i. The front wall (L.N. Barnewali Bheetri)

ii. The back wall (L.N. Pachhewali Bheetri)

iii. The side wall (Chanda)

iv. The roof (Tapri)

v. The gate

The four walls of a rectangular house are made up of mud and leaves of Saccharum officinarum. Now a days due to low rainfall, the Saccharum is not available and therefore, straw of Triticum aestivum is commonly used. On the walls, the roof is made using Phoenix sylvestris or Acacia catechu stem as girder and leaves of phoenix sylvestris to cover it. On two small front and back walls a lenter is applied which is known as Myar, on the Myar three short pillars are used known as Mulvari, the mulvari are supporting polls for three lenters, girders applied on side walls. These long lenters are called Khankwari. On khankwari transverse sticks of wood of Acacia nilotica or Anogeissus pendula are used but recently the bamboo is commonly used. After this the horizontal longitudinal strips of bamboo are applied and then this is covered by kelu.

The gate is made up of wood of Acacia nilotica. Sometimes a rectangular screen made up of frame of bamboo filled with Phoenix sylvestrics leaves. This screen is tied along one end to a pole to keep it moving for opening and closing.

Mats prepared from Phoenix sylvestris leaflets are used to sitting in gatherings. A symbol of God Ganesha locally known as Mandpo prepared from wood of Magifera indica is used at the gate of the hut during marriage. A basket made of Bamboo is generally used as a trap for chickens as well as for fishing.

Slight variations in selection of timber observed in the neighboring villages are enumerated.

Beams : (Myar, Adia) Phoenix sylvestris, Acacia nilotica.

Pillars : (Khankwari) Phoenix sylvestris, Acacia nilotica.

Poles : Anogeissus pendula

Gates : Acacia nilotica, Azadirachta indica.

Uses of plants with their different parts in the construction of huts and hutments are given in table 1.

Table 1. Plants and plant materials used for making huts.

\begin{tabular}{|c|c|c|c|}
\hline Sr. No. & Name of species & Plant parts used & Uses \\
\hline 1. & Acacia nilotica (L.) Willd. ex Del. ssp. indica (Benth.) Brenan & Stem \& branches & $\begin{array}{l}\text { Framework of roof, windows and } \\
\text { doors }\end{array}$ \\
\hline 2. & Acacia catechu (L. f.) Willd. & Stem & Beams \\
\hline 3. & Acacia leucophloea (Roxb.) Willd. & Stem & Beams \\
\hline 4. & Acacia senegal (L.) Willd. & Stem & Supporting pillars \\
\hline 6. & Anogeissus latifolia (Roxb. ex DC.)Wall. ex Guill. \& Perr. & Stem and tender branches & $\begin{array}{l}\text { Framework of roof, windows and } \\
\text { doors }\end{array}$ \\
\hline 8. & Azadirachata indica A. Juss. & Stem and branches & $\begin{array}{l}\text { Framework of roof, windows and } \\
\text { doors }\end{array}$ \\
\hline 9. & Bambusa arundinacea (Retz.) Roxb. & Culms & $\begin{array}{l}\text { Framework of roof, Thatching of hut } \\
\text { walls. }\end{array}$ \\
\hline 10. & Boswellia serrata Roxb. ex Coleb. & Stem & Pillars and doors \\
\hline 11. & Butea monosperma (Lam.) Taub. & Stem, branches and leaves & Doors, pillars and framework of roof \\
\hline 12. & Cajanus cajan (L.) Mill. & Stem & Roof \\
\hline 13. & Calotropis procera (Ait.) Ait. f. ssp. hamiltonii (Wight) Ali & Stem & Framework of roof \\
\hline 14. & Capparis decidua (Forssk.)Edgew. & Stem & Framework of roof \\
\hline
\end{tabular}




\begin{tabular}{|c|c|c|c|}
\hline Sr. No. & Name of species & Plant parts used & Uses \\
\hline 16. & Diospyros melanoxylon Roxb. & Stem & $\begin{array}{l}\text { Framework of roof, windows and } \\
\text { doors }\end{array}$ \\
\hline 17. & Gossypium herbaceum L. & Stem & Doors and walls \\
\hline 18. & Madhuca indica J. F. Gmelin & Stem & Doors and beams \\
\hline 20. & Phoenix sylvestris (L.) Roxb. & Stem and leaves & Beams, walls, gates and roof \\
\hline 23. & Saccharum bengalense Retz. & Culms and leaves & Thatching of walls and roof. \\
\hline 24. & Tectona grandis $\mathrm{L}$. & Stem \& Leaves & Beams \& roof \\
\hline 25. & Terminalia bellirica (Gaertn.) Roxb. & Stem & Beams \\
\hline 26. & Terminalia crenulata Roth & Stem & Beams \\
\hline 27. & Triticum aestivum $\mathrm{L}$. & Culms and leaves & Thatching of walls and roof. \\
\hline 28. & Typha angustata Bory \& Chaub. & Culms and leaves & Walls and roof \\
\hline 29. & Zey mays $\mathrm{L}$. & Culms and leaves & Walls and roof \\
\hline 30. & Ziziphus mauritiana Lam. & Stems and branches & Roof \\
\hline 31. & Ziziphus nuттиlaria (Burm. f.) Wight \& Arn. & Stems and branches & Framework of walls. \\
\hline
\end{tabular}

\section{Local Terms Related to Huts \& Shelters}

Shelter : Asro

Hut : Jhunpari, tapri

Raw materials for making a hut : Jugar.

Rising walls on both sides of huts : Chando

Wall behind hut : Paseet

Wall : Bheet

Foundation : Anchhot

Small room : Orri

Roof : Chhappar

Plastered ground of hut : Lippen
Balcony : Mundari

Crosswise pole : Danda

Pillars : Thambo

Main vertical pole : Thambo

Gate constructed for entry into hut compound as well as field : Tati

The knob for closing door : Kari

Latch : Hakri, sankli

Window : Kiwari

Plastering (by clay / cow dung) : Lippen

A place meant for cattle resting : Dharyo, Chhapari

Sites for tying cattle (Thann) : Barro

Watch place (Machaan): Daglo, dagro (Plate 1D)

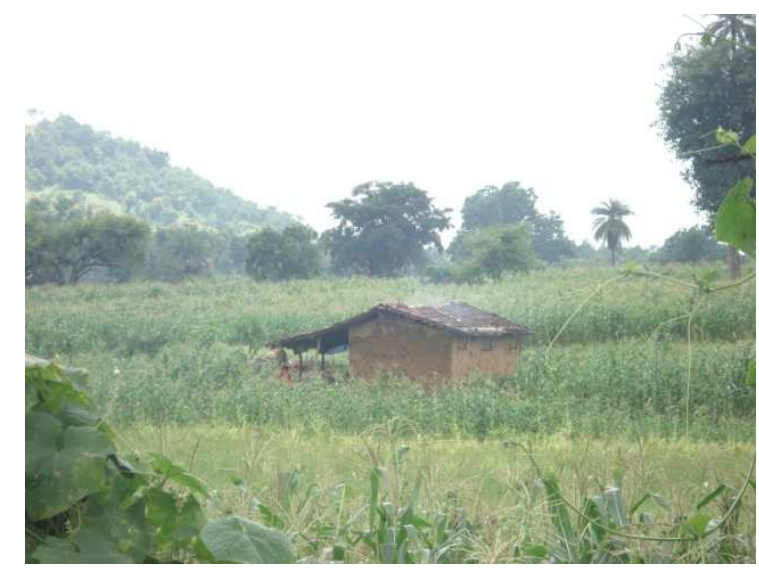

Plate 1A: A typical Hut of tribes surrounded by Agricultural field.

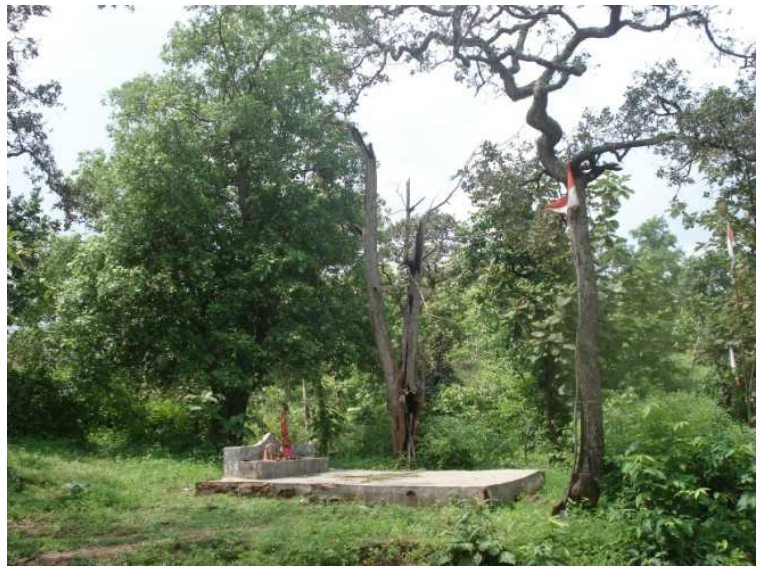

Plate 1B: Thanak of Tribes in Sitamata Wildlife Sanctuary. 


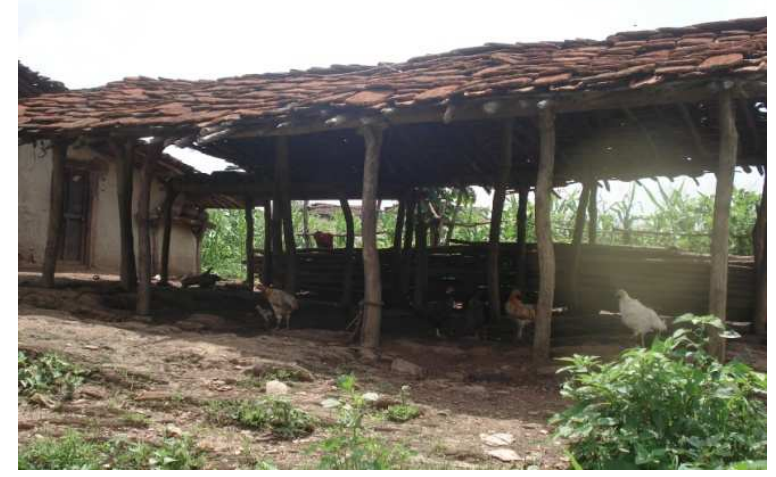

Plate $C$ : Huts for cattle and pet animals.

\section{Discussion}

The observations recorded during the present investigations of the flora of the Sitamata wildlife sanctuary may now be discussed in the light of researches carried out by earlier workers in this context.

The remarkable feature of Rajasthan is the Aravalli range, perhaps the oldest folded mountain range in the world. It intersects Rajasthan from end to end, diagonally running from Delhi to the plains of Gujarat for a distance of about $692 \mathrm{~km}$. Within Rajasthan the range runs from Khetri in the northeast to Khed Brahma in the south-west for a length of about $550 \mathrm{~km}$. The elevation of the Aravalli range gradually rises in south-west direction, as it is $335 \mathrm{~m}$ at Delhi and in Rajasthan $792 \mathrm{~m}$ at Khetri, $913 \mathrm{~m}$ at Harshnath, $920 \mathrm{~m}$ at Kho, $1055 \mathrm{~m}$ at Raghunathgarh, $1100 \mathrm{~m}$ at Bijapur and $1727 \mathrm{~m}$ at Mt. Abu. Further, south-west wards, the elevation gradually decreases to the plains of Gujarat.

The loftiest and the most clearly defined section of the Aravalli is in between Mt. Abu and Ajmer where the range stands like a barricade. Beyond Ajmer to the northeast, there are gaps in the Aravalli range near Sambhar, east of Sikar etc. Structurally, it is composed of rocks belonging originally to the Delhi system, folded in a Synclinorium occupying the site of geosyncline which has been deeply eroded. Aravalli range divides the whole of Rajasthan into two natural divisions i.e. three fifth lying on north-west and two fifth on the east and southeast.

The present status of forest everywhere is a matter of deep concern as they are gradually declining and disappearing from the countryside. Their presence in agricultural lands, grazing, fragmentation of the groveowning families, erosion of cultural \& religious beliefs, introduction of Lantana camara L., Parthenium hysteriophorus L., Spigelia anthelmia and taboos are the major reasons. In view of this, and due to failure of pure legal protective measures in guaranteeing conservation, it has become imperative to search for alternative solutions based on indigenous knowledge of the people. The tribes of this region conserve medicinal plants and the forest patches

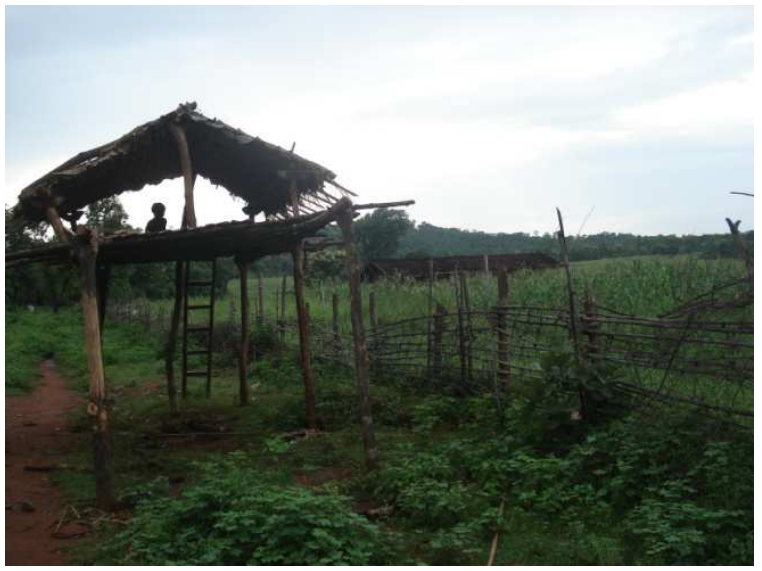

Plate 1D: Watch place (Machaan): Daglo, dagro

rich in biodiversity and play an important role in their sustainable manner with their socioeconomic and religious practice with the belief in nature worship inherited from generation after generations. Tribe believes that if the habitat of the medicinal plant species is protected theses species will be multiplied without any conservation practices.

The forest represents a long tradition of environmental conservation by the tribes of this Santuary. Therefore, there is an urgent need not only to protect forest, but also to revive and reinvent such traditional practices of nature conservation and environmental management. Initially only two species namely Commiphora wightii (Arn.) Bhandari and Rosa involucrata Roxb. were included in the threatened species from state by BSI but now this list has been increased and including the number of species in this category. The species like Anogeissus sericea Brandis var nummularia King ex Duthie Ceropegia vincaefolia Hook. emend. Ansari and Chlorophytum borivilianum Sant. et Fernand is rare and included in the red data book of Indian plants and some species like Citrullus colocynthis (L.) Schrad., C. wightii (Arn.) Bhandari and Tecomella undullata (Sm.) Seem, are reported as threatened species(Meena \& Yadav, 2006, Meena, 2012). The gum of C. wightii (Arn.) Bhandari hasan importance in international trade and it appears to be being extracted at unsustainable rates, causing declines, so presently it is included in IUCN Red List of Threatened species. In Rajasthan these species are widely distributed in the western part of the state, but here it is also reported as rare and threatened species in this district. Among the present species many are facing various threats in this region.

The danger of extinction on such species are ahead, therefore it is necessary to ensure the survival of germplasm by their protection, conservation, multiplication and maximum afforestation of such medicinal and economically important plant species. Because of limited resources of this tribe it is essential for a biotechnologist to come forward for in-situ conservation through tissue culture, establishment of botanical gardens or ex-situ 
conservation by way of protecting the forest region of the state. The political as well as involvement of NGOs may play an important role in the protection of this valuable area of the state.

\section{Acknowledgement}

Authors are highly thankful to all the tribal informants for their cooperation and help during ethnobotanical study. Help rendered by Shree Jetha Ram Ji, Laxman Ram Ji, Limba Ram Ji, Modan Ji, Nana Ram Ji, Ram Chandra Ji, Salira Ram Ji and Vikram Ji by way of providing traditional knowledge is thankfully acknowledged. Thanks are also due to Shri Bhanwar Singh Ji Meena, Additional Superintendent of Police, district Sirohi for his cooperation during these studies. Authors are thankful Principal, Vice Principals for providing the facilities. Financial assistance provided by UGC Bhopal is gratefully acknowledged.

\section{References}

[1] P.C. Ahir, S. Hussain\& Dhaka, V. 2012.Some Traditional Ethnoveterinary Medicinalplants of Kumbhalgarh wildlife sanctuary, Rajasthan, India. In: Meena, K. L. (Ed.) Proc. Nat Conf. Biod. Cons: Caus. Cons. andSol. MLV GC Bhlwara pp - 207-211.

[2] Deora, G.S., Singh, G.P. \& Jhala, G.P. 2002. Ethno-medicobotanical diversity of Kotra, Udaipur. In (Eds.) Biodiversity : Strategies for conservation. A.P.H. Publishing Corporation, New Delhi. 317-329.

[3] Duthie, J.F. 1903-1929. Flora of the Upper Gangetic Plains and of the adjascettt Siwalik and Sub - Himalayan tract. Calcutta.

[4] Gupta, R.S. \& Jiyalal. 1997. Traditional herbal remedies. In Devendra Sharma (Ed.) Compendium on phytomedicine, Council for Development of Rural Area. New Delhi. 375379.

[5] Jain, A., Katewa, S.S., Choudhary, B.L. \& Galav, P.K. 2004. Folk Herbal medicines used in birth control and Sexual diseases by tribals of Southern Rajasthan, India. $J$. Ethnopharmacology. 90(1):171-177.

[6] Jain, A., Katewa, S.S., Galav, P.K. \& Sharma, P. 2005b. Medicinal plant diversity from the Sitamata wild life sanctuary. Chittorgarh district India. J. Ethnopharmacology 102 (3): 543-557.

[7] Katewa, S. S. \& Arora, A. 1997. Some plants of folk medicine of Udaipur district, Rajasthan. Ethnobotany. $9: 48$ -51 .

[8] Katewa, S.S. \& Galav, P.K. 2005. Traditional Folk Herbal Medicines from Shekhawati Region of Rajasthan. Indian Journal of Traditional Knowledge 4 (3): 237-245.

[9] Katewa, S.S. \& Guria, B.D. 1997. Ethnomedicinal observations on certain wild plants from Southern Aravalli hills of Rajasthan : Vasundhara. $2: 85-88$.

[10] Katewa, S.S. \& Jain, A. 2006. Traditional Folk Herbal Medicines. Apex Publishing House, Udaipur.
[11] Katewa, S.S. \& Sharma, R. 1998. Ethnomedicinal observation from certain watershed areas of Rajasthan. Ethnobotany $10: 46-49$.

[12] Katewa, S.S., Chaudhary, B.L., Jain, A. \& Galav, P.K. 2003. Traditional uses of plant biodiversity from Aravalli hills of Rajasthan. Indian Journal of Traditional Knowledge 2 (I) : 27-39.

[13] Meena K. L. 2010. Morinda coreia Buch.-Ham.: A new record to the flora of Rajasthan. J. Indian. Bot. Soc. Vol. 89. (1-2): $210-212$.

[14] Meena, K. L. \& Yadav, B. L. 2006. Some important medicinal plants of Bhilwara district Rajasthan, India. Proceedings National Conference on Biodiversity Conservation. MLV Govt. College, Bhilwara. pp. 84 - 89.

[15] Meena, K. L. \& Yadav, B. L. 2007. Some ethnomedicinal plants of Rajasthan. In: P. C. Trivedi (Ed.) Ethnomedicinal Plants of India. pp. 33-44. Aavishkar publishes Distributors, Jaipur.

[16] Meena, K. L. \& Yadav, B. L. 2008. Floral resources of Rajasthan with special reference to Sitamata wildlife sanctuary. Geographical aspects. Proceedings of the $35^{\text {th }}$ National conference of Rajasthan geography Association. MLV Government College, Bhilwara. Vol. IX : 56 - 65.

[17] Meena, K.L. \& Yadav, B.L. 2006. Some important medicinal plants of Bhilwara District Rajathan, India. Proc. Nat. Conf. Biod. cons. MLV GC Bhlwara PP - 84-89.

[18] Meena, K.L. \& Yadav, B.L. 2007. Some ethnomedicinal plants of Rajasthan. In P. C. Trivedi (Edt.) Ethnomedicinal plants of India. pp.33-44. Aavishkar publishers distributors, Jaipur (India).

[19] Meena, K.L. \& Yadav, B.L. 2010a. Some Ethnomedicinal Plants of Southern Rajasthan. Indian Journal of traditional knowledge. Vol. 9 (1): 169 - 172.

[20] Meena, K.L. \& Yadav, B.L. 2010b. Some Traditional Ethnomedicinal Plants of Southern Rajasthan. Indian Journal of traditional knowledge. Vol. 9 (3): 471 - 474.

[21] Meena, K.L. \& Yadav, B.L. 2010c. Spigelia anthelmia L. (Spigeliaceae) : A New Generic Record to the Flora of Rajasthan. J. Indian. Bot. Soc. Vol. 89. (3\&4): 258 - 261.

[22] Meena, K.L. 2011. Ethnobotany Of Garasia Tribe, Rajasthan, India. LAP LAMBERT Academic Publishing, 66123 Saarbrücken

Germany.

[23] Meena, K. L. 2013.Flora of Wildlife Sanctuary. Discovery Publishing House Pvt. Ltd. New Delhi.

[24] Meena, K. L., Ahir, P.C. and Dhaka, V. 2013.Ethnomedicinal survey of medicinal plants for sexual debility and birth control by tribals of Southern Rajasthan, India. The Journal of Ethnobiology and Traditional Medicine. Photon 118: 238-244.

[25] Mena, K.L. 2012.Angiospermic Diversity of District Bhilwara from Rajasthan, India. The Journal of Biodiversity. Photon 112: 193-204

[26] Rajawat, K.S. 1990. Traditional system of tribal medicine and medicinal herbs. Project Report, M.L.V. Tribal Research Institute. Udaipur. 
[27] Rathore, M.S. 2002. Studies on traditional uses of wild plants by tribes in Kotra region, Udaipur, Rajasthan, Ph.D. Thesis, M.L. Sukhadia University, Udaipur.

[28] Roxburgh, W. 1820-1824. Flora Indica (Edited by W. Carey \& N. Wallich). Serampore. 1(1820); 2(1824).

[29] Sebastian, M. K. \& Bhandari, M.M. 1984a. Magicoreligious beliefs about plants among the Bhils of Udaiour district of Rajasthan. Folklore 4:77-80.

[30] Sebastian, M. K. \& Bhandari, M. M. 1984b. Medicoethnobotany of Mt. Abu, Rajasthan. J. Ethnopharmacol. 12(2) : 223 - 230.

[31] Sebastian, M. K. \& Bhandari, M. M. 1988. Medicinal plant lore of Udaipur district, Rajasthan. Bull. Med. Ethnobot. Res. 5(3-4): 133 - 134.

[32] Shetty, B. V. \& Singh, V. (Edits.) 1987. Flora of Rajasthan. Vol. I. BSI, Howrah.
[33] Shetty, B. V. \& Singh, V. (Edits.) 1991. Flora of Rajasthan. Vol. II. BSI, Howrah.

[34] Shetty, B.V. \& Singh, V. (Edits.) 1993. Flora of Rajasthan. Vol. III. BSI, Howrah.

[35] Shringi, O.P. 1981. Botany of Jhalawar District, Rajasthan-1. Grasses. J. Econ. Tax. Bot.2 : 85-105.

[36] Singh, V. \& Pandey, R.P. 1998. Ethnobotany of Rajasthan, India. Scientific Publishers (India), Jodhpur.

[37] Trivedi, P.C. 2002. Ethnobotany. Aavishkar Publishers, Distributors, Jaipur India.

[38] Vyas, M.S. 1987. Ferns and Fern allies of Rajasthan : Ethnobotany and Biochemical Analysis. Ph.D. Thesis. University of Jodhpur, Jodhpur (India).

[39] Yadav, B. L. \& Meena, K. L. 2011. Flora of South Central Rajasthan. Scientific Publishers Jodhpur. 